Article

\title{
Studies with Azinylacetonitriles: 2-Pyridylacetonitrile as a Precursor to Functionally Substituted Pyridines
}

\author{
Mariam Abdullah Al-Sheikh ${ }^{1, *}$ and Mohamed Hilmy Elnagdi ${ }^{2}$
}

1 Department of Chemistry, Girls College of Education, Jeddah, P. O. Box 138016, Jeddah 21323, Kingdom of Saudi Arabia

2 Department of Chemistry, Faculty of Science, Kuwait University, Kuwait

* Author to whom correspondence should be addressed; E-Mail: r1425@hotmail.com.

Received: 7 September 2009; in revised form: 27 October 2009 / Accepted: 28 October 2009 / Published: 3 November 2009

\begin{abstract}
Pyridylacetonitrile (1) couples with aromatic diazonium salts to yield arylhydrazones 2a-c, that were shown to exist in the syn-form 2 rather than the anti-form 4. Compounds 2a,c reacted with hydroxylamine in refluxing DMF to yield the interesting 1,2,3-triazolylpyridines 6. Attempts to cyclize 2 to give the corresponding fused pyrazolopyridines $\mathbf{9}$ failed. On the other hand, compound $\mathbf{1}$ condensed with dimethylformamide dimethyl acetal to yield enaminonitrile $\mathbf{1 0}$ that could be converted into pyrazolylpyridine 11.
\end{abstract}

Keywords: 2-pyridylacetonitrile; enaminonitrile; arylhydrazones

\section{Introduction}

It is well accepted that the methylene moieties in heteroaromatic substituted acetonitriles are reactive toward electrophiles under mild conditions [1-3]. This reactivity has been utilized for synthesis of a variety of functionally substituted azoles [4,5] and condensed azoles [6,7]. However, little has been reported on the utility of azinylacetonitriles for synthesis of functionally substituted azines [8]. 


\section{Results and Discussion}

In conjunction with our interest in using aromatic and heteroaromatic substituted acetonitriles as precursors for the synthesis of heteroaromatics, we report herein the reactivity of 2-pyridylacetonitrile (1) as a good precursor to several azolylpyridines. Thus, compound $\mathbf{1}$ coupled with aromatic diazonium salts to yield arylhydrazones 2a-c. Although a mixture of the two geometrical isomers was expected based on an earlier report [9], the existence of only the syn-structure 2 could be established, at least in the solid state, based on X-ray crystal structure determination [10] (cf. Figure 1 and Table 1 for bond angles and bond lengths).

Scheme 1. Syntheses of hydrazones.

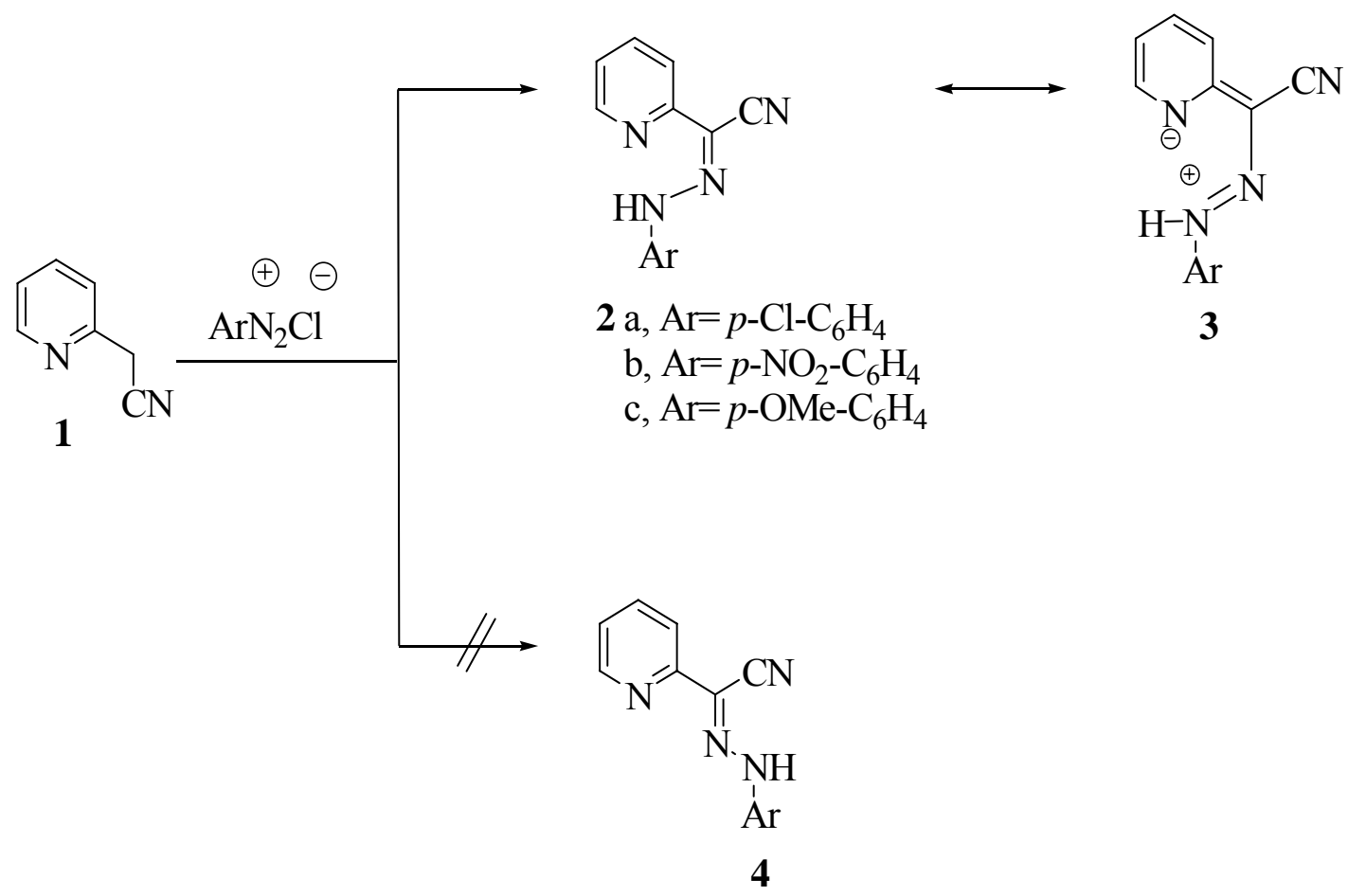

Figure 1. X-ray crystal structure of compound 2a.

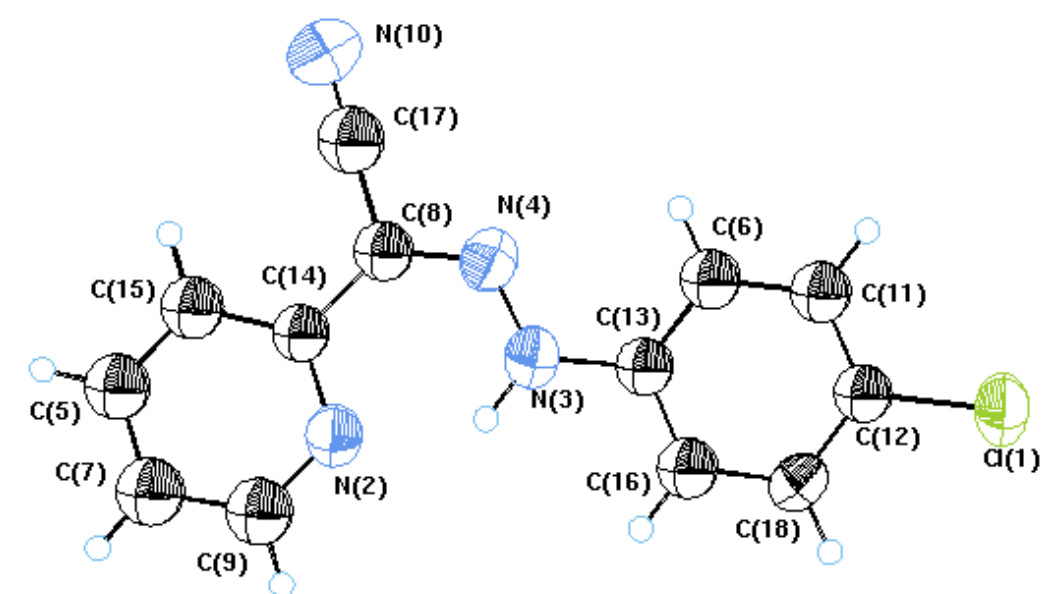


Table 1. Crystal data and structure refinement for compound 2a.

\begin{tabular}{|l|l|}
\hline Parameter & \multicolumn{1}{|c|}{ 2a } \\
\hline Empirical Formula & $\mathrm{C}_{13} \mathrm{H}_{9} \mathrm{~N}_{4} \mathrm{Cl}$ \\
\hline Formula weight & 256.696 \\
\hline Crystal System & Monoclinic \\
\hline Space group & $\mathrm{P} 21 / \mathrm{c}$ \\
\hline Unit cell parameters & \\
$\mathrm{a}[\AA]$ & $8.4969(3)$ \\
$\mathrm{b}[\AA]$ & $13.5879(6)$ \\
$\mathrm{c}[\AA]$ & $12.8704(6)$ \\
alpha & 90.00 \\
$\mathrm{~B}^{\mathrm{o}}$ & $12 .(18) 10^{10}$ \\
gamma & 90.00 \\
\hline Unit cell volume & $1228.62(9)$ \\
$\mathrm{Z}$ & 4 \\
\hline Temperature $(\mathrm{K})$ & 298 \\
\hline Radiation type & Mo Ka \\
\hline Dx Mg/m & \\
\hline F $(000)$ & 1.388 \\
\hline Absorption coefficient & 528 loop \\
(mm $\left.{ }^{-1}\right)$ & 0.30 \\
\hline Parameters & 103 \\
\hline R factor & 0.061 \\
\hline
\end{tabular}

\begin{tabular}{|l|l|l|l|}
\hline \multicolumn{2}{|c|}{ Bond lengths } & \multicolumn{2}{c|}{ Bond lengths } \\
\hline N4 C8 & $1.320(4)$ & N3 N4 & $1.326(4)$ \\
\hline N2 C9 & $1.326(5)$ & N3 C13 & $1.412(5)$ \\
\hline N2 H3 & $1.906(3)$ & C6 C13 & $1.363(5)$ \\
\hline C8 C17 & $1.449(5)$ & C1 1 C12 & $1.742(3)$ \\
\hline N2 C14 & $1.349(4)$ & N10 C17 & $1.143(4)$ \\
\hline N4 H3 & $1.985(3)$ & C13 C16 & $1.377(4)$ \\
\hline
\end{tabular}

\begin{tabular}{|l|l|l|c|}
\hline \multicolumn{2}{|c|}{ Bond angles } & \multicolumn{2}{c|}{ Bond angles } \\
\hline N3 N4 C8 & $118.6(3)$ & N2 C14 C8 & $116.9(3)$ \\
\hline C14 C8 C17 & $118.5(3)$ & N2 H3 N3 & $132.7(2)$ \\
\hline N2 C9 C7 & $124.3(4)$ & N3 H3 N4 & $35.4(2)$ \\
\hline C8C17 N10 & $179.3(4)$ & C8 C14C15 & $122.1(3)$ \\
\hline N3C13 C6 & $122.2(3)$ & N4 C8 C14 & $130.4(3)$ \\
\hline N4 N3 C13 & $118.4(3)$ & N3 C13C16 & $117.6(3)$ \\
\hline
\end{tabular}

Inspection of Table 1 indicates that the acetonitrile N4-C8-C14 bond angle is larger than a typical $\mathrm{sp}^{2}$ bond angle $\left(120^{\circ}\right)$, perhaps to reduce the steric interaction between hydrogen $\mathrm{NH}$, and the pyridyl ring N3-N4 bond length is more like a double bond. We assume that nitrogen lone pair is delocalized at the ring nitrogen and that electrostatic attraction between the positively charged hydrazone moiety and the negatively charged ring nitrogen holds the molecule in the syn-form. It is thus concluded that charge separation in 2 contributes significantly to the actual structure [10-12].

Compounds 2a,b reacted with hydroxylamine hydrochloride in refluxing DMF and in the presence of sodium acetate to yield the products of addition and water elimination which can thus be formulated as 1,2,3-triazoles $\mathbf{6 a , b}$ or their isomeric structures 1,2,4-triazoles 7, and are assumed to be formed via the intermediately formed amidoximes 5a,b that could be isolated (Scheme 2). NOE difference spectra enabled the assignment of structure 6 for the products as irradiation of the $\mathrm{NH}_{2}$ protons at $\delta=6.3 \mathrm{ppm}$ did not enhance the aryl protons. If the reaction product were 7 enhancement of these aryl protons should have been observed. The behavior of 2 towards hydroxylamine is thus similar to that of other hydrazononitriles and differs from that of 2-p-nitrophenyl-2-arylhydrazonoacetonitrile where rearrangement preceded cyclization affording 1,2,4-triazoles 7. Although 2-arylhydrazono-2acetylpyridine 8 has been recently reported to afford 9 when heating in dichlorobenzene at $190{ }^{\circ} \mathrm{C}$, in our hands, compounds 2a-c have been recovered unaffected under these conditions [13]. It seems that replacing a methyl by a cyano group affects the HOMO-LUMO energy of the cyclised $6 \pi$ electron system as this cyclization is believed to proceed by a pericyclic rule. Next, compound $\mathbf{1}$ was reacted 
with DMFDMA to yield the corresponding enaminonitrile 10, for which exact stereochemistry could not be established. Reacting 10 with hydrazine hydrate afforded aminopyrazole derivative 11, in good yield (cf. Scheme 3 ). The ${ }^{1} \mathrm{H}-\mathrm{NMR}$ of compound $\mathbf{1 1}$ revealed three singlets at $\delta=5.60,7.90$ and 11.76 ppm for the exocyclic $\mathrm{NH}_{2}$, pyrazole $\mathrm{CH}$ and pyrazole $\mathrm{NH}$ protons, respectively.

Scheme 2. Syntheses of 1,2,3-triazoles.

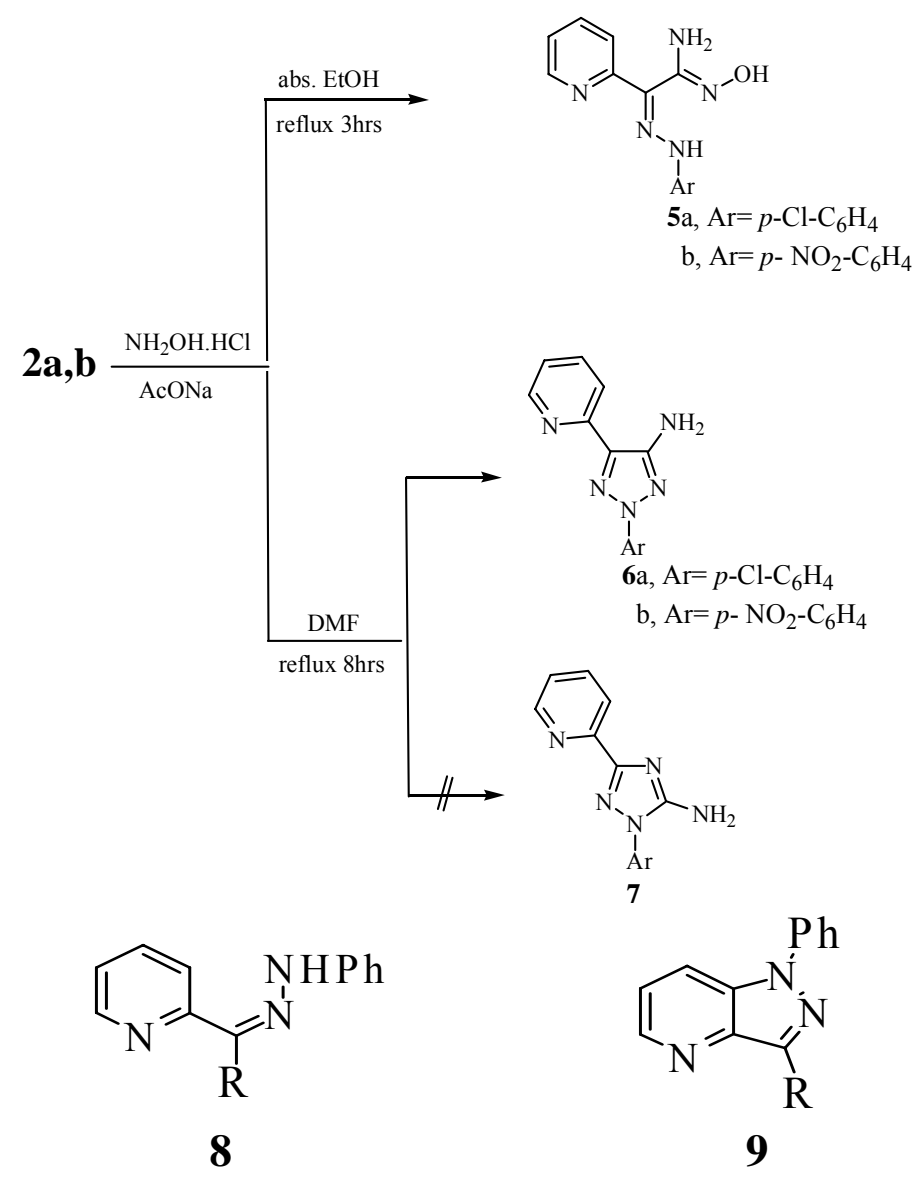

Scheme 3. Reactions of the enaminonitrile $\mathbf{1 0 .}$

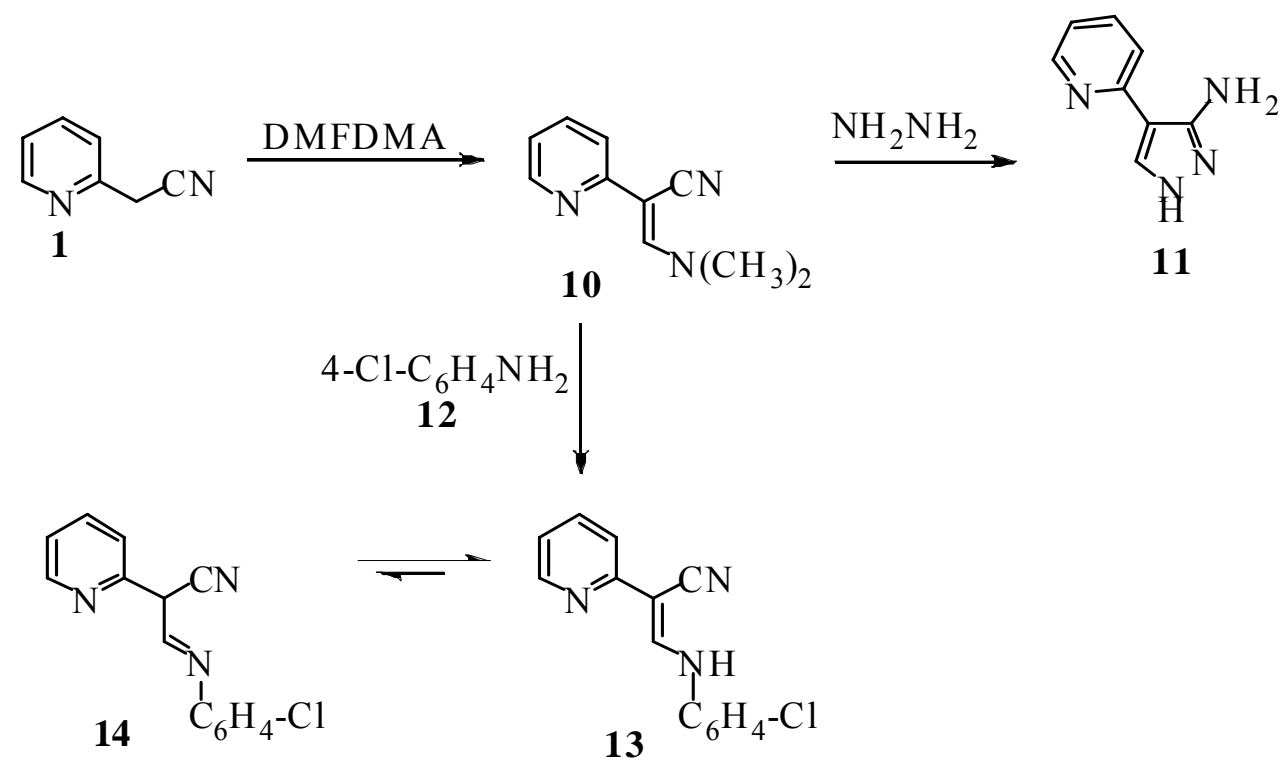


Compound 10 reacted with $p$-chloroaniline 12 to give compound 13. Structure 14 was excluded based on ${ }^{1} \mathrm{H}-\mathrm{NMR}$ and ${ }^{13} \mathrm{C}-\mathrm{NMR}$ that revealed the absence of signals for a $\mathrm{sp}^{3}$ carbon or protons linked to such a carbon (Scheme 3). It can thus be concluded that while compound $\mathbf{1}$ is a versatile precursor to azolylpyridines, conversion of compound 2 to pyrazolo[4,3-b]pyridine via a route similar to that reported for converting 8 into $\mathbf{9}$ could not be effected, at least under the conditions reported in the published work [13].

\section{Experimental}

\section{General}

All melting points were measured on Gallenkamp electrothermal melting point apparatus and are uncorrected. Microwave synthesis were carried out in SJO390W microwave oven. IR spectra were recorded as $\mathrm{KBr}$ pellets on a Pye Unicam SP 3-300 spectrophotometer. ${ }^{1} \mathrm{H}-\mathrm{NMR}$ spectra were recorded in deuterated dimethylsulfoxide (DMSO-d6) at $300 \mathrm{MHz}$ on a Varian Gemini NMR spectrometer using tetramethylsilane (TMS) as an internal reference and results are expressed as $\delta$ values. Mass spectra were performed on a Shimadzu GCMS-QP 1000 Ex mass spectrometer at $70 \mathrm{eV}$. Elemental analyses were performed by the Microanalytical Center at Cairo University. The crystal structure was determined by the X-ray unit at the National Research Center, Dokki, Cairo.

General procedure for the synthesis of arylhydrazones 2a-c

A cold solution of aryldiazonium salt $(10 \mathrm{mmol})$, prepared by adding a solution of sodium nitrite (10 mmol in $10 \mathrm{~mL}$ of water) to a cold solution of arylamine hydrochloride (10 mmol of arylamine in 6 $\mathrm{mL}$ of $\mathrm{HCl})$ with stirring, was added to a cold solution of 2-pyridylacetonitrile $(\mathbf{1}, 10 \mathrm{mmol})$ in ethanol $(50 \mathrm{~mL})$ containing sodium acetate trihydrate $(10 \mathrm{mmol})$. The mixture was then stirred at room temperature for $1 \mathrm{~h}$ and the resulting solid product was collected by filtration, washed well with water, dried and recrystallized from ethanol.

[(4-Chlorophenyl)hydrazono]pyridine-2-yl-acetonitrile (2a): Orange crystals (92\%); mp.147-148 ${ }^{\circ} \mathrm{C}$; IR $\left(\mathrm{cm}^{-1}\right): 3258(\mathrm{NH}), 2212(\mathrm{CN}),{ }^{1} \mathrm{H}-\mathrm{NMR}: \delta=7.50-8.10(\mathrm{~m}, 4 \mathrm{H}, \mathrm{pyr}-\mathrm{H}), 8.58(\mathrm{~d}, 2 \mathrm{H}, J=7.2 \mathrm{~Hz}$, Ar-H), 8.70 (d, $2 \mathrm{H}, J=7.2 \mathrm{~Hz}, \mathrm{Ar}-\mathrm{H}), 15.03$ (s, $1 \mathrm{H}, \mathrm{NH})$; Anal. Calcd. for $\mathrm{C}_{13} \mathrm{H}_{9} \mathrm{ClN}_{4}$ (256.69): C, 60.83; H, 3.53; N, 21.83. Found: C, 60.64; H, 3.60; N, 21.64. MS (EI): $\mathrm{m} / \mathrm{z}(\%)=255\left(\mathrm{M}^{+}-1\right)$.

[(4-Nitrophenyl)hydrazono]pyridine-2-yl-acetonitrile (2b): Orange crystals (90\%); mp. 217-219 ${ }^{\circ} \mathrm{C}$; IR $\left(\mathrm{cm}^{-1}\right): 3241(\mathrm{NH}), 2218(\mathrm{CN})$; ${ }^{1} \mathrm{H}-\mathrm{NMR}: \delta=7.40-8.20(\mathrm{~m}, 4 \mathrm{H}, \mathrm{pyr}-\mathrm{H}), 8.63(\mathrm{~d}, 2 \mathrm{H}, J=7.3 \mathrm{~Hz}$, Ar-H), 8.65 (d, 2H, $J=7.3 \mathrm{~Hz}, \mathrm{Ar}-\mathrm{H}), 15.25$ (s, $1 \mathrm{H}, \mathrm{NH}$ ); Anal. Calcd. for $\mathrm{C}_{13} \mathrm{H}_{9} \mathrm{~N}_{5} \mathrm{O}_{2}$ (267.24): C, 58.43; H, 3.39; N, 26.21. Found: C, 58.27; H, 3.29; N, 25.91. MS (EI): $m / z(\%)=267\left(\mathrm{M}^{+}\right)$.

[(4-Methoxyphenyl)hydrazono]pyridine-2-yl-acetonitrile (2c): Yellow crystals (81\%); mp.181-182 ${ }^{\circ} \mathrm{C}$; IR $\left(\mathrm{cm}^{-1}\right): 3250(\mathrm{NH}), 2216(\mathrm{CN}) ;{ }^{1} \mathrm{H}-\mathrm{NMR}: \delta=3.70\left(\mathrm{~s}, 3 \mathrm{H}, \mathrm{CH}_{3}\right), 6.90-8.07(\mathrm{~m}, 4 \mathrm{H}, \mathrm{pyr}-\mathrm{H}), 8.60(\mathrm{~d}$, $2 \mathrm{H}, J=7.0 \mathrm{~Hz}, \mathrm{Ar}-\mathrm{H}), 8.70(\mathrm{~d}, 2 \mathrm{H}, J=7.0 \mathrm{~Hz}, \mathrm{Ar}-\mathrm{H}), 15.03$ (s, 1H, NH); ${ }^{13} \mathrm{C}-\mathrm{NMR}: \delta=156.1,151.9$, 150.0, 147.7, 139.1, 136.2, 123.2, 121.1, $119.1(\mathrm{CN}), 116.8,114.8,55.3\left(\mathrm{OCH}_{3}\right)$; Anal. Calcd. for 
$\mathrm{C}_{14} \mathrm{H}_{12} \mathrm{~N}_{4} \mathrm{O}$ (252.27): C, 66.65; H, 4.79; N, 22.21. Found: C, 66.72; H, 4.82; N, 22.28. MS (EI): $\mathrm{m} / \mathrm{z}$ $(\%)=252\left(\mathrm{M}^{+}\right)$.

\section{General procedure for the synthesis of compounds $\mathbf{5 a , b}$}

To a mixture of arylhydrazononitriles $2 \mathbf{2 a}, \mathbf{b}(10 \mathrm{mmol})$ and hydroxylamine hydrochloride $(10 \mathrm{mmol})$ in absolute ethanol $(20 \mathrm{~mL})$, anhydrous sodium acetate $(2 \mathrm{~g})$ was added and the reaction mixture was then refluxed for $3 \mathrm{hrs}$. After cooling to room temperature, the mixture was poured into water and the resulting precipitate collected by filtration, washed with water, dried and recrystallized from ethanol.

2-[(4-Chlorophenyl)hydrazono]-N-hydroxy-2-yl-acetamidine (5a): Yellow crystals (80\%); mp.164$165{ }^{\circ} \mathrm{C}$; IR (cm $\left.{ }^{-1}\right): 3495(\mathrm{OH}), 3390,3273\left(\mathrm{NH}_{2}\right), 3185(\mathrm{NH}) ;{ }^{1} \mathrm{H}-\mathrm{NMR}: \delta=5.60\left(\mathrm{~s}, 2 \mathrm{H}, \mathrm{NH}_{2}\right), 7.20-$ 8.0 (m, 4H, pyr-H), 8.50 (d, 2H, J = 7.1 Hz, Ar-H), 8.70 (d, 2H, J = 7.1 Hz, Ar-H), 10.17 (s, 1H, NH), 12.8 (s, 1H, OH); Anal. Calcd. for $\mathrm{C}_{13} \mathrm{H}_{12} \mathrm{ClN}_{5} \mathrm{O}$ (289.73): C, 53.89; H, 4.17; N, 24.17. Found: C, 53.79; H, 3.99; N, 24.20. MS (EI): $\mathrm{m} / \mathrm{z}(\%)=288\left(\mathrm{M}^{+}-1\right)$.

2-[(4-Nitrophenyl)hydrazono]-N-hydroxy-2-yl-acetamidine $\quad(5 b): \quad$ Orange $\quad$ crystals $\quad(80 \%)$; mp.284-285 ${ }^{\circ} \mathrm{C}$; IR $\left(\mathrm{cm}^{-1}\right): 3495(\mathrm{OH}), 3382,3270\left(\mathrm{NH}_{2}\right), 3179(\mathrm{NH}) ;{ }^{1} \mathrm{H}-\mathrm{NMR}: \delta=5.20(\mathrm{~s}, 2 \mathrm{H}$, $\mathrm{NH}_{2}$ ), 7.40-8.0 (m, 4H, pyr-H), 8.30 (d, 2H, $\left.J=7.0 \mathrm{~Hz}, \mathrm{Ar}-\mathrm{H}\right), 8.70$ (d, 2H, J = 7.0 Hz, Ar-H), 8.90 (s, $1 \mathrm{H}, \mathrm{NH}), 15.2$ (s, 1H, OH); Anal. Calcd. for $\mathrm{C}_{13} \mathrm{H}_{12} \mathrm{O}_{3} \mathrm{~N}_{5}$ (300.27): C, 52.0; H, 4.03; N, 27.99. Found: C, 52.10; H, 3.98; N, 28.02. MS (EI): $m / z(\%)=300\left(\mathrm{M}^{+}\right)$.

\section{General procedure for the synthesis of compounds $\mathbf{6 a}, \mathbf{b}$}

To a mixture of arylhydrazononitriles $\mathbf{2 a} \mathbf{a} \mathbf{b}(10 \mathrm{mmol})$ and hydroxylamine hydrochloride $(10 \mathrm{mmol})$ in DMF $(20 \mathrm{~mL})$, anhydrous sodium acetate $(2 \mathrm{~g})$ was added. Then, the reaction mixture was refluxed for $8 \mathrm{hrs}$. The solvent was evaporated under vacuum and the crude product was collected by filtration, washed with ethanol, dried and recrystallized from ethanol/dioxane.

2-(4-Chlorophenyl)-5-pyridin-2-yl-2H-[1,2,3]triazol-4-ylamine $\quad(\mathbf{6 a}): \quad$ Yellow crystals (80\%); mp.167-169 ${ }^{\circ} \mathrm{C}$; IR $\left(\mathrm{cm}^{-1}\right)$ : 3303, $3155\left(\mathrm{NH}_{2}\right)$; ${ }^{1} \mathrm{H}-\mathrm{NMR}: \delta=6.30\left(\mathrm{~s}, 2 \mathrm{H}, \mathrm{NH}_{2}\right), 7.30-8.0(\mathrm{~m}, 4 \mathrm{H}, \mathrm{pyr}-$ H), $8.02(\mathrm{~d}, 2 \mathrm{H}, J=7.2 \mathrm{~Hz}, \mathrm{Ar}-\mathrm{H}), 8.6(\mathrm{~d}, 2 \mathrm{H}, J=7.2 \mathrm{~Hz}, \mathrm{Ar}-\mathrm{H}) ;{ }^{13} \mathrm{C}-\mathrm{NMR}: \delta=152.8,150.7,148.8$, 137.9, 137.2, 132.1, 130.3, 129.4, 122.3, 119.7, 118.7; Anal. Calcd. for $\mathrm{C}_{13} \mathrm{H}_{10} \mathrm{ClN}_{5}$ (271.70): C, 57.47; H,3.71; N, 25.78. Found: C, 57.31; H, 3.68; N, 25.89. MS (EI): $m / z(\%)=271\left(\mathrm{M}^{+}\right)$.

2-(4-Nitrophenyl)-5-pyridin-2-yl-2H-[1,2,3]triazol-4-ylamine $\quad(\mathbf{6 b}): \quad$ Orange $\quad$ crystals $\quad(79 \%)$; mp. $280{ }^{\circ} \mathrm{C}$; IR $\left(\mathrm{cm}^{-1}\right): 3336,3278\left(\mathrm{NH}_{2}\right) ;{ }^{1} \mathrm{H}-\mathrm{NMR}: \delta=6.50\left(\mathrm{~s}, 2 \mathrm{H}, \mathrm{NH}_{2}\right), 7.30-8.11(\mathrm{~m}, 4 \mathrm{H}, \mathrm{pyr}-\mathrm{H})$, 8.30 (d, 2H, $J=7.3 \mathrm{~Hz}, \mathrm{Ar}-\mathrm{H}), 8.68$ (d, 2H, $J=7.3 \mathrm{~Hz}, \mathrm{Ar}-\mathrm{H}) ;{ }^{13} \mathrm{C}-\mathrm{NMR}: \delta=157.1,150.0,148.4$, 137.7, 135.0, 132.1, 130.0, 129.0, 124.0, 122.0, 119.0, Anal. Calcd. for $\mathrm{C}_{13} \mathrm{H}_{10} \mathrm{~N}_{6} \mathrm{O}_{2}$ (282.26): C, 55.32; H, 3.57; N, 29.77. Found: C, 55.20; H, 3.46; N, 29.69. MS (EI): $m / z(\%)=282\left(\mathrm{M}^{+}\right)$.

Synthesis of 3-dimethylamino-2-pyridin-2-yl-acrylonitrile (10): A mixture of compound 1 (10 mmol) and dimethylformamide dimethylacetal (DMFDMA) $(10 \mathrm{mmol})$ was irradiated in a domestic 
microwave oven for 1 minute at $240 \mathrm{~W}$. The mixture was left standing overnight and the resulting solid product was collected by filtration, washed with ethanol, dried and recrystallized from ethanol to give compouned 10 as brown crystals (80\%), mp.116-118 ${ }^{\circ} \mathrm{C}$; IR $\left(\mathrm{cm}^{-1}\right)$ : $2221(\mathrm{CN})$; ${ }^{1} \mathrm{H}-\mathrm{NMR}$ : $\delta=2.48\left(\mathrm{~s}, 6 \mathrm{H}, 2 \mathrm{CH}_{3}\right), 6.90-8.60\left(\mathrm{~m}, 4 \mathrm{H}\right.$, pyr-H), $8.07(\mathrm{~s}, \mathrm{H}$, olefinic $\mathrm{CH})$; Anal. Calcd. for $\mathrm{C}_{10} \mathrm{H}_{11} \mathrm{~N}_{3}$ (173.21): C, 69.34; H, 6.40; N, 24.26. Found: C, 69.41; H, 6.41; N, 24.17. MS (EI): $\mathrm{m} / \mathrm{z}(\%)=173$ $\left(\mathrm{M}^{+}\right)$.

Synthesis of 4-pyridin-2-yl-2H-pyrazol-3-yl-amine (11): A mixture of compound 10 (10 mmol) and hydrazine hydrate $(80 \%, 10 \mathrm{mmol})$ was irradiated in a domestic microwave oven for 2 minutes. The resulting solid product was collected by filtration, washed with ethanol, dride and recrystallized from ethanol to give compound 11 as brown crystals (75\%); mp. $120-121{ }^{\circ} \mathrm{C}$; ${ }^{1} \mathrm{H}-\mathrm{NMR}: \delta=5.60(\mathrm{~s}, 2 \mathrm{H}$, $\left.\mathrm{NH}_{2}\right), 6.90-8.40\left(\mathrm{~m}, 4 \mathrm{H}\right.$, pyr-H), $7.90\left(\mathrm{~s}, 1 \mathrm{H}\right.$, pyrazole H-5), $11.76(\mathrm{~s}, 1 \mathrm{H}, \mathrm{NH}) ;{ }^{13} \mathrm{C}-\mathrm{NMR}: \delta=155.1$, 151.1, 148.8, 136.8, 133.4, 119.0, 118.7, 103.0; Anal. Calcd. for $\mathrm{C}_{8} \mathrm{H}_{8} \mathrm{~N}_{4}$ (160.20): C, 59.99; H, 5.03; N, 34.98. Found: C, 60.01; H, 4.98; N, 34.87. MS (EI): m/z (\%) $=160\left(\mathrm{M}^{+}\right)$.

Synthesis of 3-(4-chlorophenylamino)-2-pyridin-2-ylacrylonitrile (13): To a mixture of p-chloroaniline 12 (10 mmol) and compound 10 (10 mmol), a drop of $\mathrm{AcOH}$ was added, then the mixture was irradiated in a domestic microwave oven for 2 minutes at $280 \mathrm{~W}$. The resulting solid product was collected by filtration, washed with ethanol, dried and recrystallized from ethanol to give compound 13 as colourless crystals (86\%); mp. 179-180 ${ }^{\circ} \mathrm{C}$; IR $\left(\mathrm{cm}^{-1}\right)$ : $3387(\mathrm{NH}), 2202(\mathrm{CN})$; ${ }^{1} \mathrm{H}-\mathrm{NMR}$ : $\delta=7.1-8.2(\mathrm{~m}, 4 \mathrm{H}$, pyr-H), $8.40(\mathrm{~d}, 2 \mathrm{H}, J=7.2 \mathrm{~Hz}, \mathrm{Ar}-\mathrm{H}), 8.50(\mathrm{~s}, \mathrm{H}$, olefinic $\mathrm{CH}), 8.60(\mathrm{~d}, 2 \mathrm{H}, J=$ $7.2 \mathrm{~Hz}, \mathrm{Ar}-\mathrm{H}$ ), 12.60 (brs, 1H, NH); ${ }^{13} \mathrm{C}-\mathrm{NMR}: \delta=156.0,150.0,149.0,144.0,137.0,130.0,123.0$, 122.0, 121.0, $119.0(\mathrm{CN}), 116.0$, 103.0; Anal. Calcd. for $\mathrm{C}_{14} \mathrm{H}_{10} \mathrm{ClN}_{3}$ (255.7): C, 65.76; H, 3.94; $\mathrm{N}, 16.43$. Found: $\mathrm{C}, 65.59 ; \mathrm{H}, 3.99 ; \mathrm{N}, 16.52$. MS (EI): $\mathrm{m} / \mathrm{z}(\%)=254\left(\mathrm{M}^{+}-1\right)$.

\section{Conclusions}

In conclusion, a new simple approach to 2,5-disubstituted-1,2,3-triazole-5-amines from 2-arylhydrazononitriles has been achieved.

\section{References}

1. Elnagdi, M.H.; Selim, M.A.; Abd El Latif, F.M.; Samia, S. Studies on azolylacetonitriles: The reactivity of thiazol-2-yl, thiadiazol-2-yl acetonitriles toward electrophilic reagents. Phosphor. Sulfur Silicon 2002, 177, 1175-1182.

2. Klimko, Y.E.; Pisanenko, D.A. Addition of acetonitrile to 5-methylene- and 5ethylidenebicyclo[2.2.1] hept-2-enes in the Ritter reaction. Ukr. Khim. Zh. 2008, 74, 104-108.

3. Ghozlan, S.A.S.; Abdelhamid, I.A.; Ibrahim, H.M.; Elnagdi, M.H. Studies with 2-arylhydrazononitriles: A new convenient synthesis of 2,4-disubstituted-1,2,3-triazole-5-amines ARKIVOC 2006, XV, 53-60.

4. Bey, E.; Marchais-Oberwinkler, S.; Werth, R.; Negri, M.; Al-Soud, Y.A.; Kruchten, P.; Oster, A.; Frotscher, M.; Birk, B.; Hartmann, R.W.D. Synthesis, Biological evaluation and 
pharmacokinetics of bis(hydroxyphenyl) substituted azoles, thiophenes, benzenes, and azabenzenes as potent and selective nonsteroidal inhibitors of $\beta$-hydroxysteroid dehydrogenase type 1 (17ß -HSD1). J. Med. Chem. 2008, 51, 6725-6739.

5. Al-Matar, H.M.; Riyadh, S.M.; Elnagdi, M.H. 2-Arylhydrazononitriles in heterocyclic synthesis: A novel route to 1,3-diaryl-1,2,4-triazol-5-amines via a Tiemann rearrangement of arylhydrazonoamidoximes. ARKIVOC 2007, XIII, 53-62.

6. Itoh, T.; Matsuzaki, K.; Suzuki, S.; Kishida, K.; Ogura, H.; Kawahara, N.; Nakajima, T. Photochemical reactions of condensed azoles with dimethyl acetylenedicarboxylate. IV. Heterocycles 1983, 20, 1321-4132.

7. Riyadh, S.M.; Al-Matar, H.M.; Elnagdi, M.H. Studies with 2-Arylhydrazononitriles: Further Investigations on reactivity of 2-Arylhydrazononitriles towards hydroxylamine. J. Heterocycl. Chem. 2008, 45, 1-5.

8. Volovenko, Y.M.; Nemazanyi, A.G.; Vesel'skaya, G.L.; Babichev, F.S. Synthesis of condensed azines with a backbone nitrogen atom under intramolecular nucleophilic substitution in the series of thiophene derivatives. Ukr. Khim. Zh. 1987, 53, 1085-1088.

9. Ghozlan, S.A.S.; Abdelhamid, I.A.; Elnagdi, M.H. Functionally substituted arylhydrazones as building blocks in heterocyclic synthesis: routes to pyridazinesand pyridazinoquinazolines. ARKIVOC 2006, XIII, 147-157.

10. Crystal data for $\mathbf{2 a}$ (ref. CCDC 743498) can be obtained on request from the Director, Cambridge Crystallographic Data Center, 12 Union Road, Cambridge CB2 1EZ, UK.

11. Altomare, A.; Cascarano, G.; Giacorazzo, C.; Guaghardi, A.; Burla, M.C.; Polidori, G.; Camalli, M. SIR92-A program for automatic solution of crystal structures by direct methods. J. Appl. Cryst. 1994, 27, 435.

12. Johnson, C.K. ORTEP-11. Oak Ridge National Laboratory: Oak Ridge, TN, USA, 1976.

13. Filak, L; Rokob, T.A; Vasko, G.A.; Egyed, O. Gomory, A; Riedl, Z.; Hajos, G. A new cyclization to fused pyrazoles tunable for pericyclic or pseudopericyclic route: An experimental and theoretical study. J. Org. Chem. 2008, 73, 3900-3906.

Sample Availability: Samples of the compounds 1-13 are available from the authors.

(C) 2009 by the authors; licensee Molecular Diversity Preservation International, Basel, Switzerland. This article is an open-access article distributed under the terms and conditions of the Creative Commons Attribution license (http://creativecommons.org/licenses/by/3.0/). 